\title{
KONSEP LIABILITI DAN PEMBERIAN PAMPASAN GANTI RUGI DALAM KEMALANGAN JALAN RAYA MENURUT PERUNDANGAN ISLAM
}

\author{
${ }^{1}$ Siti Khadijah Mohd Khair, ${ }^{2}$ Nuarrual Hilal Md Dahlan \& \\ ${ }^{3}$ Harlida Wahab \\ ${ }^{1,2 \& 3}$ School of Law, College of Law, Government and \\ International Studies, Universiti Utara Malaysia
}
sitikhadijahmohdkhair@gmail.com; hilal@uum.edu.my; harlida@uum.edu.my

Received: 7/11/2018 Revised: 24/6/2019 Accepted: 4/7/2019 Published: 31/7/2019

\begin{abstract}
ABSTRAK
Aspek liabiliti dan pemberian pampasan ganti rugi merupakan perkara utama dalam membincangkan isu kesalahan kecuaian di dalam kes kemalangan jalan raya. Artikel ini bertujuan untuk menganalisa konsep liabiliti dalam kemalangan jalan raya menurut perundangan Islam dengan memfokuskan kepada kesalahan kecuaian dengan menggunakan pendekatan kualitatif. Dhaman atau denda ganti rugi dalam kajian ini akan menekankan prinsip khusus dan pendekatan ke atas aspek perlanggaran di jalan raya di dalam perundangan Islam. Kajian perpustakaan digunakan untuk liabiliti di dalam kes-kes perlanggaran berteraskan AlQuran, sunnah, ijma'dan qiyas. Seterusnya ia menghubungkaitkan pemakaian konsep ini dengan kesalahan kecuaian menyebabkan perlanggaran di dalam kemalangan jalan raya. Dapatan kajian menunjukkan prinsip 'penyebab' dalam perundangan Islam amat jelas pemakaian dan perkaitannya di dalam menentukan liabiliti sama ada kes perlanggaran berlaku di daratan, lautan atau di ruang udara. Konsep liabiliti turut terpakai bagi menentukan tanggungan kecuaian dan pemberian pampasan ganti rugi oleh pihak-pihak yang terlibat dalam membina struktur jalan, jambatan, terowong dan lain-lain. Konsep ini juga berhubung dengan jalan raya sekiranya tanggungan bukan pada pemandu yang tidak bersalah dan tidak cuai.
\end{abstract}


Kata kunci: Liabiliti, Pampasan ganti rugi, Kecuaian, Perlanggaran, Perundangan Islam.

\begin{abstract}
The aspects of liability and compensation have been key points when discussing the issue of negligence in road traffic accidents. This article aims to analyze the concept of liability in road accidents, in accordance to Islamic law, that focuses on negligence by using a qualitative approach. The application of 'dhaman' or the compensation of damages, is a broad concept that will be examined in this study. Furthermore, this study will review the specific principles and approaches on collisions of road traffic within the Islamic law. The methodology carried out employs the use of library study to analyze the concept of liability in cases of collisions, based on the Al-Quran, sunnah, ijma' and qiyas with regards to the application of 'dhaman' on the negligence that have resulted in collisions from road accidents. The research outcome suggests that the 'causal' principle in Islamic law is very clear on its application and relevance in determining the liability of either a case of collision that has occurred on the road, ocean or in air. The concept of liability is also applied to determine the liability of negligence and awarded compensation by the parties that are involved in constructing the roads, bridges, tunnels and other structures that are associated with the road, if the liability does not fall upon the innocent and negligent drivers.
\end{abstract}

Keywords: Liability, Damages, Negligence, Collision, Islamic Law.

\title{
PENGENALAN
}

Berita tentang kemalangan ngeri yang banyak meragut nyawa dan menyebabkan kecederaan parah sentiasa disiarkan dan dipaparkan di saluran media massa. Menurut data statistik yang dikeluarkan oleh pihak Kementerian Pengangkutan Malaysia, secara amnya telah dilaporkan sebanyak 6,740 orang mangsa telah terkorban akibat kecelakaan jalan raya pada tahun 2017 manakala jumlah mangsa yang mengalami kecederaan berat ialah 3,310 orang. Jumlah 
kemalangan jalan raya bagi keseluruhan pada tahun 2017 adalah paling tinggi jumlahnya iaitu sebanyak 533,875 kes. (Buku Statistik Keselamatan Jalan Raya, Kementerian Pengangkutan Malaysia, 18 April 2018), Pertambahan angka ini amat besar jumlahnya dari tahun ke tahun yang paling tinggi statistik kematian mengikut pengguna bagi tahun 2017 adalah jenis kenderaan melibatkan motorsikal yang mencatatkan jumlah tertinggi iaitu sebanyak 4,348 kes.

Statistik kemalangaan jalan raya yang diperoleh daripada Institut Penyelidikan Keselamatan Jalan Raya atau MIROS (Buku Statistik Keselamatan Jalan Raya, Jabatan Keselamatan Jalan Raya Malaysia, 2018) menyatakan faktor-faktor yang menyumbang kepada kemalangan jalan raya di Malaysia adalah $80.6 \%$ disebabkan kelalaian manusia, $13.2 \%$ berpunca dari keadaan atau kondisi jalan raya manakala kenderaan hanya menyumbang 6.2 peratus daripada kemalangan yang berlaku. Hal ini menunjukkan kadar kemalangan jalan raya di Malaysia sentiasa berada pada paras kritikal dan yang berlaku perlu diambil perhatian oleh semua pihak. Satu kemalangan jalan raya boleh memberi kesan yang buruk terhadap kesihatan mangsa, kewangan dan kehidupan mangsa serta ahli keluarga mangsa itu sendiri. Selain itu, ia turut menyebabkan kehilangan nyawa, kerosakan pada kenderaan, kecederaan anggota badan, penderitaan, kesakitan dan kesedihan kepada mangsa serta ahli keluarga mangsa yang terlibat.

Di samping itu, industri insurans kenderaan di Malaysia melaporkan membayar dalam anggaran RM14.7 juta sehari bagi tuntutan pampasan ganti rugi kes kemalangan jalan raya melalui wawancara bersama Pengerusi Insurans Am Malaysia (PIAM), Antony Lee (Akhbar The Sun Daily, 22.11.2018). Nilai tuntutan ganti rugi termasuk kerosakan harta benda, kecederaan diri serta kecurian kenderaan dan yang lebih merunsingkan ialah jumlah kematian akibat kemalangan jalan raya yang tinggi. Berdasarkan statistik yang dikongsi beliau, jumlah premium yang dipungut oleh syarikat insurans dalam tahun 2017 ialah RM8.32 billion iaitu meningkat dari RM8.16 billion dalam tahun 2016. Sementara itu, jumlah kematian akibat kemalangan jalan raya tahun 2016 ialah sebanyak 7,152 kes justeru menyebabkan kerugian ekonomi pada negara untuk satu kematian antara RM2 juta ke RM3 juta. Sehubungan itu, diharapkan apabila industri insurans kenderaan sudah diliberalisasikan, 
pengguna yang sering melanggar undang-undang jalan raya akan dikehendaki membayar premium tahunan yang lebih tinggi. Faktor ini diharap memberi kesedaran kepada pengguna atau pemandu mematuhi jalan raya.

Pemahaman bersandarkan bahawa pampasan kerugian sepertimana yang disebut di dalam Surah An-Nisa ayat 92 berhubung pembunuhan secara tersalah dan pampasan kerugiannya, serta pampasan kerugian yang turut dinyatakan di dalam Surah Al-Maidah ayat 45 berhubung pampasan mengenai kecederaan tubuh badan adalah tidak dapat dielakkan melainkan pemandu itu bersalah atau tidak, sama ada kejadian itu boleh dijangkakan oleh manusia biasa untuk dikendalikan dan dielakkan atau sama ada mangsa itu sendiri turut menyumbang kecuaian dan bertanggungan terhadap kemalangan itu atau tidak. Akan tetapi, satu penelitian dalam perundangan Islam telah mengetengahkan pelbagai perbezaan di dalam penganalisaan yang menumpukan amalan syariat Islam serta satu ketetapan yang amat baik telah dilakukan oleh para sarjana Islam dan ulama yang tidak memisahkan diri mereka daripada norma pemikiran dan prinsip keadilan sejagat.

\section{PENYATAAN MASALAH}

Berdasarkan senario ini, kajian ini akan menganalisis tentang konsep liabiliti dan pemberian pampasan ganti rugi dalam kes kemalangan jalan raya menurut perundangan Islam. Selari dengan teknologi kenderaan berenjin dan permotoran telah wujud pada zaman kini, maka kesinambungan perbincangan fuqaha' dahulu boleh diteruskan dengan menyumbang pendapat dalam menghuraikan isu berkaitan kemalangan jalan raya pada zaman kini. Seterusnya perbincangan mengenai perkara ini dapat dilakukan secara terperinci oleh kerana prinsip-prinsip di dalam perundangan Islam mengenainya telah ada (Al-Kasani, 1986; Ahmad Fathi al-Dirini, 1998) dan bersedia untuk diperkembangkan. Dhaman bermaksud kewajipan (Al-Khatib, Juzuk 2). Pengertian ini telah digunakan bagi maksud yang lebih luas iaitu sinonim dengan al-haqq al-shakhsi (hak persendirian), taghrim (denda), mujib (tanggungjawab), dayn (hutang), dhaman (ganti rugi) dan sebagainya (Wahbah al-Zuhayli, 1404H/1982M). Ia merupakan satu tajuk yang amat luas namun kajian ini akan menekankan 
prinsip-prinsip khususnya pendekatan ke atas aspek perlanggaran. Topik ini relevan dan signifikan untuk diketengahkan supaya dapat dilaksanakan kefahaman syariat Islam secara komprehensif tentang konsep liabiliti khususnya di dalam menentukan isu tanggungan yang wujud bagi kesalahan dan kecuaian pihak-pihak sama ada terlibat secara langsung atau tidak langsung di dalam kes perlanggaran khususnya di dalam kes kemalangan jalan raya seterusnya pemberian pampasan ganti rugi kepada mangsa di dalam kemalangan tersebut dapat diberikan secara bijaksana dan adil.

\section{OBJEKTIF}

Artikel ini bertujuan untuk menganalisa penulisan di dalam kitabkitab ulama klasik dan kontemporari berkaitan dengan konsep asas liabiliti terhadap kecuaian jalan raya serta ganti rugi yang akan ditanggung oleh 'aqilah iaitu orang yang membayar diyat (Al-Jurjani, 2000). Selain itu, ia juga bertujuan untuk mengenalpasti pendekatan yang diambil oleh para fuqaha' dalam membuktikan kepekaan mereka dalam konteks semasa apabila membincangkan secara khusus berhubung kemalangan yang melibatkan kapal laut iaitu pengangkutan yang paling moden pada masa itu selain kenderaan berupa haiwan tertentu yang digunakan sebagai pengangkutan utama di jalan darat. Dalam mengemukakan perbincangan mengenai kemalangan jalan raya pada masa kini, sumber rujukan sedia ada mengenai haiwan tertentu akan tetap digunakan.

\section{METODOLOGI KAJIAN}

Kajian ini menggunakan kaedah penulisan metod kajian kualitatif iaitu mengkaji konsep liabiliti di dalam kes-kes perlanggaran berteraskan sumber yang utama iaitu al-Quran dan hadis diikuti kaedah-kaedah seperti qiyas, masalih mursalah, istihsan dan sebagainya dapat digunakan dalam membuat ijtihad baharu tentang hukum mengenai perkara-perkara baharu yang wujud pada zaman sains dan teknologi dalam konteks masa kini. Instrumen keperpustakaan merupakan sumber utama yang digunakan untuk mendapatkan hasil kajian terdahulu melalui kitab asli, buku serta jurnal berkaitan isu yang dibincangkan. Data-data yang diperoleh 
dianalisa dengan teliti dalam bentuk deskriptif untuk menghasilkan rumusan kajian yang akurat.

\section{ASAS LIABILITI DI DALAM PERUNDANGAN ISLAM}

Rujukan penting terhadap kefahaman Islam berhubung liabiliti (tanggungan) dan dhaman (denda ganti rugi) sepertimana yang telah ditetapkan di dalam Al-Quran iaitu:

"Dan (ingatlah) akan Daud dan Sulaiman, ketika keduanya menghukum (memberi keputusan) tentang tanaman (seorang peladang), ketika kambing kaum terlepas (masuk) ke dalamnya (lalu dimakannya) dan adalah Kami menjadi saksi atas hukumannya itu. Lalu Kami fahamkan (terangkan) hukuman itu kepada Sulaiman; masing-masing Kami berikan hukum (keputusan) dan ilmu pengetahuan. Kami tundukkan gunung-gunung dan burung-burung kepada Daud, semuanya bertasbih menyucikan Tuhan. Dan Kamilah yang membuatnya." (Surah Al-Anbiya, 21: 78-79)

Berdasarkan ayat ini, tanaman yang telah diadili oleh Daud dan Sulaiman itu telah diceritakan oleh para rawi seperti berikut: ada dua orang lelaki datang di hadapan Nabi Daud a.s., seorang darinya tuan punya tanaman atau ladang dan menurut satu riwayat yang lain ialah ladang kurma dan penternak kambing. Tuan punya tanaman telah mendakwa bahawa kambing-kambing itu telah memasuki ladang tanamannya di waktu malam dan merosakkannya hingga semua tanaman musnah, lalu Daud a.s. menjatuhkan hukuman iaitu tuan punya ladang boleh mengambil kambing-kambing penternak sebagai ganti tanamannya yang rosak itu. Kemudian penternak kambing itu datang mendapatkan Sulaiman a.s. dan menceritakan keputusan hukuman yang dijatuhkan oleh Daud a.s. lalu Sulaiman a.s. pun mengadap ayahandanya Daud sambil bersabda: "Wahai Nabiyullah, hukuman yang lebih adil bukannya seperti hukuman yang dijatuhkan oleh ayahanda".

Daud a.s. terus bertanya: "Bagaimana hukumannya?" Jawab Sulaiman: "Serahkan kambing-kambing itu kepada tuan punya 
ladang supaya dia dapat mengambil manfaat dari ternakan itu dan serahkan ladang itu kepada penternak kambing itu supaya dia dapat memperbetulkan kerosakan yang telah berlaku kepada ladang itu sehingga pulih seperti sediakala dan selepas itu pulangkan semula kepada tuan punya masing-masing hak kepunyaannya iaitu tuan punya ladang mengambil balik bendangnya dan penternak kambing mengambil balik kambing-kambing ternakannya". Lalu Daud a.s. pun bersabda: "Hukuman yang diputuskan oleh anakanda ini adalah lebih adil". Lalu Daud pun meminda keputusannya dan mengenakan hukuman yang telah diputuskan oleh Sulaiman (Asy-Syahid Sayyid Qutb Rahimahullah, 2000/1420H).

Keputusan hukuman yang dibuat oleh Daud a.s. dan Sulaiman a.s. dalam kes di atas merupakan keputusan yang dibuat menurut ijtihad mereka masing-masing dan kedua-dua hukuman itu telah disaksikan oleh Allah SWT, kemudian Allah SWT mengilhamkan kepada Sulaiman a.s. hukuman yang lebih adil dan bijaksana dan memahamkan beliau hukuman itu dan itulah hukuman yang lebih tepat. Hukuman Daud a.s. semata-mata bertujuan memberi ganti rugi kepada tuan punya ladang tanaman dan tujuan ini sudah pun cukup adil, tetapi hukuman Sulaiman a.s. di samping mendukung dasar keadilan, ia juga merupakan hukuman yang membina yakni keadilan hukuman ini mendorong ke arah keadilan yang dinamik dan positif. Itulah hukuman melalui ilham yang dikurniakan oleh Allah SWT kepada siapa sahaja yang dikehendakiNya. Kedua-dua Daud a.s. dan Sulaiman a.s. itu telah dikurniakan kebijaksanaan dan ilmu pengetahuan namun tiada apa-apa kesalahan di dalam keputusan hukuman yang dijatuhkan Daud a.s., tetapi keputusan hukuman yang diberikan Sulaiman a.s. adalah lebih tepat kerana keputusan itu adalah dari ilham Ilahi.

Secara prinsipnya, orang awam berhak menggunakan jalan raya sama ada berkenderaan atau berjalan kaki. Islam memandang jalan raya sebagai satu kemudahan awam yang dapat membawa manusia ke destinasi yang dituju dengan cepat dan selamat. Maka, ia mempunyai hak-hak dan peraturan yang harus dipatuhi oleh semua pengguna supaya fungsi jalan raya itu tidak disalahgunakan melalui perlanggaran hak dan peraturannya. Merujuk sebuah hadis Rasulullah SAW yang bermaksud: 
Dari Abu Said al-Khudri bahawa Nabi Muhammad SAW bersabda:

"Jauhilah duduk di jalan-jalan raya." Lalu mereka berkata, "Wahai Rasulullah, kami tidak berbuat apa-apa sekadar duduk dan berbual-bual di sana." Kemudian baginda berkata: "Jika kamu tidak berbuat apa-apa melainkan duduk-duduk sahaja, maka tunaikanlah hak-hak jalan raya." Mereka bertanya: "Apakah hak-hak jalan raya itu?" Baginda berkata, "Menundukkan pandangan, menghilangkan benda berbahaya, menjawab salam, menyuruh kepada kebaikan serta melarang perkara-perkara mungkar." (Abu Abdullah Muhammad Ibn Ismail al-Bukhari, 1983)

Nas yang seterusnya ialah perintah larangan untuk tidak menyebabkan sebarang kemudaratan kepada seseorang yang lain dan, jika kemudaratan itu telah dilakukan, mangsa tidak dibenarkan untuk menyebabkan kemudaratan sebagai satu penebusan. Daripada Abu Said Sa'ad Bin Sinan Al-Khudri RA, sesungguhnya Rasulullah SAW bersabda:

"Tidakbolehmelakukan perbuatanyang memudaratkan diri sendiri dan orang lain” (Ibn Majah (2341); alDaruqutni (4/228)

Hadis tersebut telah menggariskan beberapa prinsip asas iaitu:

(a) Semua kemudaratan yang diakibatkan ke atas tubuh badan dan harta seseorang hendaklah dijauhi.

(b) Jangan membahayakan iaitu kamu merugikan orang yang tidak merugikan kamu. Sedangkan yang dimaksudkan saling merugikan iaitu kamu membalas orang yang merugikan kamu dengan hal yang tidak setara dan tidak untuk membela kebenaran.

(c) Hadis itu bermaksud seolah-olah larangan ini berlaku terhadap orang yang memulainya sedangkan bagi orang yang melakukan pembalasan yang setimpal dan menuntut haknya tidak dikatakan berkhianat. Yang dikatakan khianat 
hanyalah orang yang mengambil sesuatu yang bukan haknya atau mengambil lebih dari haknya. Secara keseluruhannya mewujudkan perintah tanggungan terhadap mana-mana pelaku salah untuk menebus kemudaratan yang diakibatkan oleh dirinya.

Oleh yang demikian, daripada hadis tersebut dapat disimpulkan bahawa "sesuatu kecederaan yang disebabkan oleh haiwan tidak boleh dituntut", adalah tidak boleh diragui kesahihannya. Secara amnya, pendapat mengenai perkara ini, para fuqaha' telah bersepakat bagi maksud 'haiwan' terdapat batasan untuk setiap spesis haiwan termasuklah haiwan yang terbiar atau tersesat yang memakan rumput seperti lembu, unta, kambing atau haiwan pengembara seperti keldai dan seumpamanya. Isunya adalah sama ada wujud tanggungan yang diakibatkan oleh haiwan-haiwan tersebut berdasarkan kecuaian atau yang tidak diperselisihkan di kalangan ulama. Hadis tersebut telah meminimakan tanggungjawab pemilikpemilik di dalam situasi tersebut selagi mana ia tidak menjejaskan aktiviti ekonomi dan perdagangan di dalam masyarakat yang banyak bergantung kepada haiwan tersebut. Maka, sebarang perbuatan yang melanggar peraturan keselamatan jalan raya ini sehingga menyebabkan kemalangan, bergesel dan sebagainya adalah perlu dipertanggungjawabkan. Sementara itu, sebarang kerosakan yang berlaku akibat perlanggaran atau kemalangan hendaklah dibayar ganti rugi kecuali perlanggaran itu tidak dapat dielakkan ("Ala alDin al-Samarqandi, 1993).

\section{PEMAKAIAN ISTILAH KECUAIAN DALAM UNDANG-UNDANG ISLAM}

Para fuqaha klasik dan kontemporari menggunakan istilah khata' yang bererti tidak sengaja atau tersalah atau tersilap yang diberi maksud sama seperti tafrit (Ibn Qudamah, 620H/1223M) apabila membincangkan kes-kes berkaitan dengan kecuaian. Tinjauan literatur mendapati, tidak terdapat perbahasan yang khusus dan lengkap berkaitan dengan persoalan kecuaian ini. Lazimnya penggunaan perkataan ini sering digunakan oleh fuqaha' klasik apabila membincangkan mengenai perbuatan salah secara tidak sengaja atau sebagai tort kecuaian. Manakala perkataan al-taqsir atau 
qasara pula bermaksud meninggalkan sesuatu (Ibn Manzur, 1233$1312 \mathrm{M} / 711 \mathrm{H}$ ). Dari segi bahasa kedua-dua perkataan ini memberi erti kecuaian atau kurang berhati-hati bermaksud seseorang itu telah gagal melakukan suatu tindakan yang sepatutnya dilakukan sebagai seorang yang munsabah. Permasalahan tentang tanggungan bagi haiwan yang terbiar atau haiwan yang meragut rumput sepertimana yang diterangkan di dalam andaian di atas merupakan satu dimensi baru yang dapat dihubungkaitkan iaitu jalan raya dan kenderaan yang dipandu. Kajian ini adalah berhubung dengan kemalangan iaitu larangan melakukan kemudaratan ke atas tubuh badan seseorang dengan sewenang-wenangnya mahupun hartanya.

Walau bagaimanapun, jumhur ulama telah bersepakat bahawa seseorang yang menggunakan kenderaan sebagai pengangkutannya sama ada motorsikal, haiwan tunggangan, kapal, motorkar yang boleh menyebabkan kemudaratan ke atas tubuh badan orang lain atau hartanya, maka pelaku itu boleh didakwa membunuh, mencederakan atau serang sentuh yang boleh dihukum qisas (Ibn Farhun, 1995). Namun, terdapat sebahagian fuqaha di kalangan Mazhab Hanafi yang mengkategorikan kes-kes kematian tersebut sebagai shibh alamdi (pembunuhan seumpama sengaja) dan oleh itu, boleh dihukum dengan diyat mughallazah (diyat berat) dan ta'zir (Sayyid Sabiq, 2009).

Sehubungan dengan persoalan kewajipan berjaga-jaga ini, AlMarghinani yang merupakan seorang fuqaha Mazhab Hanafi menjelaskan bahawa:

Adalah menjadi peraturan bahawa hak laluan di atas jalan raya diizinkan kepada seluruh ahli masyarakat tertaklukkepadasyaratkewajipanmenjagakeselamatan terhadap pengguna lain; ini ialah hak pengguna istimewa kepada seseorang pada satu pihak dan kepada satu pihak yang lain. Ini bermaksud bahawa hak laluan dikongsi bersama-sama oleh seluruh ahli masyarakat dengan mengambil kira kepentingan kedua-dua pihak. Seterusnya, diberi perhatian bahawa sekatan kepada syarat keselamatan hanya terlaksana pada perkaraperkara yang boleh dilaksanakan kewajipan berjagajaga sahaja; sebaliknya pada perkara-perkara tidak 


\begin{abstract}
boleh dilaksanakan kewajipan berjaga-jaga, maka tiada kewajipan berjaga-jaga dipertanggungjawabkan ke atas pengguna jalan raya. (Burhan al-Din Abi alHasan 'Ali Bin Abi Bakr Bin 'Abd al-Jalil al-Rushdani, $593 \mathrm{H} / 1196 \mathrm{M})$
\end{abstract}

Islam menyarankan bahawa setiap orang yang menggunakan jalan raya atau sebarang tempat awam mempunyai kewajipan berhati-hati terhadap orang lain dan harta benda mereka. Sekiranya seseorang pengguna jalan raya memandu kenderaan dengan cuai yang akhirnya menyebabkan pengguna jalan raya lain mengalami kemalangan disebabkan kecuaiannya, maka tuntutan ganti rugi boleh diambil ke atasnya sebagai pampasan kemalangan atau kerugian itu. Contohnya kajian oleh Abdul Basir (Abdul Basir Mohamad, 2009) menyatakan bahawa jika seseorang yang memandu kenderaan atau membawa muatan dengan menggunakan kenderaan dan dia mengetahui atau menjangkakan kemungkinan berlakunya perlanggaran atau sebarang kemalangan, maka di bawah prinsip perundangan Islam, pihak tersebut mempunyai kewajipan untuk mengambil tindakan berhati-hati secara munasabah bagi mengelakkan kemalangan dan perlanggaran tersebut. Demikian juga bagi pemandu yang membawa muatan dengan menaiki kenderaan berat dan kemudiannya suatu perlanggaran terjadi yang menyebabkan muatan itu terjatuh ke atas jalan raya, maka pemandu itu bertanggungan ke atas sebarang akibat yang disebabkan oleh muatan yang terjatuh itu.

Menurut Ibn Juzayy (Abu al-Qasim Muhammad Bin Ahmad Bin Juzayy al-Kalabi al-Gharnati, 1293-1340M) ulama dari Mazhab Maliki menyatakan bahawa seseorang yang mengalami kecederaan akibat kemalangan di jalan raya tidak boleh menuntut ganti rugi, melainkan pemandu kenderaan telah terbukti bersalah atas alasan kecuaian atau terbukti wujudnya elemen ta'addi pada pihaknya ketika dia mengendalikan kenderaan itu. Peraturan umum yang dapat dinyatakan di sini ialah kenderaan mesti dipandu pada kelajuan yang sewajarnya bagi membolehkan pemandu memberhentikan, mengawal dan mengendalikan kenderaan tersebut dalam ruang, jarak dan masa yang tidak mendatangkan risiko bahaya kepada diri sendiri dan orang lain, di samping mengambil kira cuaca dan keadaan jalan raya. Kegagalan mengambil kira keadaan tersebut berkemungkinan besar boleh mengakibatkan berlakunya kemalangan jalan raya. 
Dengan demikian, pemandu wajib bertanggungan terhadap kemalangan tersebut.

\section{TANGGUNGAN DI DALAM KES-KES KEMALANGAN JALAN RAYA}

Konsep liabiliti di dalam kes kemalangan jalan raya serta pemberian pampasan kepada para mangsa merupakan keutamaan di dalam perundangan masa kini selari dengan arus pembangunan yang pesat dan meluas terutama dalam sektor pengangkutan di darat, maritim, di angkasa juga di dasar lautan.

Menurut para fuqaha mazhab Hanafi (Al-Marghinani, Burhan al-Din Abi al-Hasan 'Ali Bin Abi Bakr Bin 'Abd al-Jalil alRushdani, 593H/1196M), Maliki (Ibn Rushd, Muhammad Bin Ahmad Bin Muhammad Bin Ahmad Bin Rushd al-Qurtubi alAndalusi, w.595H/1198M) dan Hanbali (Al-Khiraqi, Umar Bin al-Husayn, 1402H/1982M) berpendapat bahawa dalam kes perlanggaran yang berlaku antara dua penunggang kenderaan yang menyebabkan kedua-dua mereka terbunuh atau hanya salah seorang daripada mereka terbunuh, maka kedua-dua penunggang tersebut bertanggungan untuk membayar diyat penuh antara satu sama lain. Walau bagaimanapun, pendapat Imam Malik sendiri yang diriwayatkan oleh Ibn Qudamah dalam penulisannya al-Mughni menyatakan bahawa dalam kes ini pihak 'aqilah bagi setiap pihak bertanggungan membayar separuh diyat sahaja, bukannya diyat penuh (Al-Khirshi, Abu 'Abd Allah Muhammad Bin 'Abd Allah, 1317H/1899M). Manakala, menurut pendapat majoriti para fuqaha mazhab ini, pembayaran diyat penuh dikenakan ke atas setiap pihak yang terlibat dalam kes tersebut. Diyat yang harus dibayar dalam kes tersebut adalah boleh dalam bentuk nilaian emas iaitu seribu dinar, nilaian perak iaitu dua belas ribu dirham, nilaian lembu iaitu dua ratus ekor, nilaian kambing iaitu dua ribu ekor atau nilaian pakaian iaitu dua ratus helai baju.

Alasan mengapa pembayaran diyat penuh dikenakan adalah kerana kematian yang dialami oleh setiap pihak semestinya dirujuk atau dibebankan keseluruhannya kepada pihak yang satu lagi dan tidak ada percampuran dengan tindakannya sendiri. Dengan erti kata 
lain, tidak wujud elemen kecuaian sertaan pada pihak mangsa yang meninggal dunia. Ini kerana atas tindakan masing-masing, iaitu penggunaan jalan raya dibenarkan secara mutlak oleh undangundang, maka tindakan yang dilakukan mengikut kebenaran yang diberikan oleh undang-undang tidak dibebankan bersama-sama dengan tanggungjawab (Al-Marghinani, Burhan al-Din Abi al-Hasan 'Ali Bin Abi Bakr Bin 'Abd al-Jalil al-Rushdani, 593H/1196M). Boleh dikatakan bahawa suatu tahap dan ukuran berhati-hati yang maksimum telah diambil oleh semua pengguna jalan raya bagi menjaga keselamatan antara satu sama lain. Oleh yang demikian, semua pengguna jalan raya tidak akan melakukan tindakan yang akan dijangkakan secara munasabah yang boleh menyebabkan kecederaan atau kemudaratan terhadap diri mereka sendiri.

Menurut Al-Zayla 'i pembayaran diyat penuh bagi setiap penunggang yang mengalami kemalangan tersebut hanya patut dibayar dalam kes kemalangan yang berlaku secara pertembungan yang terburu-buru antara satu sama lain, iaitu secara tidak sengaja (al-khata'). Sekiranya kemalangan tersebut berlaku secara sengaja (al-'amd), maka hanya separuh pembayaran diyat yang patut dibayar antara satu sama lain dengan alasan bahawa setiap seorang dianggap sebagai pembunuh pada diri sendiri (Al-Zayla'i, Fakhr al-Din Uthman Bin Ali al-Hanafi, w.762H/1360M) Para fuqaha mazhab Hanafi telah menyatakan jika dua orang lelaki masing-masing sedang menunggang binatang tunggangan dan kemudian bertembung antara satu sama lain dalam kemalangan yang akhirnya kedua-duanya meninggal dunia, maka pembayaran diyat bagi setiap seorang dibebankan kepada 'aqilah masing-masing (Al-Marghinani, Burhan al-Din Abi al-Hasan 'Ali Bin Abi Bakr Bin 'Abd al-Jalil al-Rushdani, 593H/1196M).

Sekiranya perlanggaran berlaku disebabkan oleh penunggang yang datang dari belakang yang merempuh penunggang yang sedang berjalan di hadapannya, maka tanggungan kesalahan akan dibebankan ke atas penunggang yang merempuh itu dan bukannya ke atas penunggang yang dirempuh, sekalipun dalam kes lain perlanggaran tersebut disebabkan oleh pihak yang dirempuh (Al-Baghdadi, Abu Muhammad Bin Ghanim Bin Muhammad, 1308H/1890M). Ini kerana kemungkinan kedudukan penunggang yang datang dari arah belakang dianggap mempunyai tahap dan kawalan yang tinggi terhadap tunggangannya bagi mengelakkan 
terjadinya perlanggaran. Jika perlanggaran masih berlaku, ini menjadi bukti yang jelas bahawa kecuaian pada pihak dirinya.

Dalam kes lain, sekiranya berlaku perlanggaran antara penunggang yang sedang berjalan dengan penunggang yang berhenti, maka tanggungan kesalahan ditujukan kepada penunggang yang sedang berjalan kerana rempuhan itu berpunca daripadanya dan bukannya daripada pihak yang sedang berhenti. Maka, pembayaran diyat ditanggung oleh 'aqilah penunggang yang sedang berjalan, manakala ganti rugi kerosakan kenderaan atau tunggangannya ditanggung oleh penunggang itu sendiri (Qadikhan, al-Hasan Ibn Mansur, 2009). Keputusan ini boleh diaplikasikan bagi kes perlanggaran yang terjadi kepada pejalan kaki atau sesama pejalan kaki. Ini bermakna pejalan kaki di jalan raya bertanggungjawab mengambil tindakan berhati-hati terhadap pengguna jalan raya yang lain. Sekiranya pejalan kaki tersebut gagal mengambil tindakan berhati-hati yang sewajarnya dan munasabah sehingga boleh menyebabkan kemalangan yang mencederakan pihak lain, maka dia juga bertanggungjawab membayar diyat. Justeru, apabila seseorang pejalan kaki melangkah masuk dari kaki lima jalan ke jalan raya, maka dia bertanggungjawab mengambil tindakan berhati-hati terhadap lalu lintas yang dihampirinya bagi mengelakkan dirinya dilanggar atau dirempuh oleh pengguna jalan raya lain.

Oleh itu, jika seorang pejalan kaki melangkah masuk ke lorong yang pada ketika itu penunggang sedang bergerak menuju ke arahnya yang akhirnya mengakibatkan berlaku perlanggaran yang menyebabkan penunggang itu terbunuh, maka tanggungan bagi kejadian tersebut dibebankan ke atas pejalan kaki itu. Secara ringkasnya dapat dikatakan bahawa seorang pejalan kaki boleh melintasi jalan raya di mana-mana tempat yang dikehendakinya dengan syarat dia mengambil tindakan berhati-hati yang munasabah.

Seterusnya, para fuqaha mazhab Maliki berpendapat bahawa jika sesuatu perlanggaran itu berlaku tanpa niat jenayah, iaitu terjadi secara tidak sengaja atau khata', maka pembayaran diyat diberikan kepada pihak mangsa, sama ada dia telah terbunuh dalam kejadian tersebut atau pun mengalami kecederaan, akan dibebankan ke atas 'aqilah bagi setiap seorang yang terlibat dalam kejadian itu. Tetapi, pembayaran ganti rugi terhadap kerosakan kenderaan atau harta 
benda dalam kejadian itu ditanggung oleh setiap penunggang yang terlibat dalam perlanggaran itu (Malik bin Anas, Malik Bin Anas, 1994).

Manakala salah seorang fuqaha mazhab Hanbali, iaitu Ibn Duwayyan menyatakan bahawa jika terdapat dua orang mukallaf yang merdeka berlanggar antara satu sama lain dan kedua-duanya meninggal dunia, maka pembayaran diyat dikenakan ke atas setiap seorang tetapi dibayar oleh 'aqilah masing-masing kerana setiap seorang dikira sebagai penyebab kematian antara satu sama lain. Keputusan ini berasaskan keputusan yang dibuat oleh Saidina Ali yang mengatakan kematian yang berlaku kepada setiap seorang akibat daripada kejadian perlanggaran termasuk sebagai kes pembunuhan secara tidak sengaja iaitu al-khata' (Ibn Duwayyan, Ibrahim Bin Muhammad Bin Salim, 1404H/1984M). Ini menunjukkan bahawa tanggungan dalam kes ini ialah pembayaran diyat penuh bagi setiap seorang. Dalam kes lain, jika dua orang perempuan yang sedang hamil berlanggar antara satu sama lain, maka keputusannya sama seperti dalam kes yang dinyatakan di atas. Di samping itu, setiap seorang bertanggungan separuh diyat terhadap janin yang dikandung kerana setiap seorang terlibat sebagai penyebab kepada kematiannya (Ibn Duwayyan, Ibrahim Bin Muhammad Bin Salim, 1404H/1984M).

Selain itu, menurut para fuqaha mazhab Shafi'i menegaskan apabila dua orang secara tidak sengaja bertembung antara satu sama lain sama ada antara dua orang penunggang, antara dua orang pejalan kaki atau antara pejalan kaki dengan penunggang, secara berhadapan atau secara hentaman dari belakang, maka 'aqilah bagi setiap pihak saling menanggung diyat mukhaffafah sekiranya kemalangan itu menyebabkan kematian kedua-dua pihak. Kes ini dianggap sebagai pembunuhan yang berlaku secara tidak sengaja. Keputusan ini juga boleh diterima pakai kepada kes perlanggaran yang berlaku dari arah belakang atau perlanggaran yang berlaku dari arah yang bertentangan. Jika perlanggaran itu berlaku secara sengaja pada kedua-dua belah pihak, 'aqilah masing-masing bertanggungan membayar separuh diyah mughallazah. Kes ini dianggap sebagai pembunuhan separuh sengaja (shibh al- 'amd) kerana perlanggaran pada kebiasaannya tidak menyebabkan kematian. Namun, sekiranya elemen niat sengaja hanya boleh dibuktikan pada sebelah pihak 
sahaja, maka pihak berkenaan sahaja yang bertanggungan membayar diyat.

Mengikut sesetengah pendapat para fuqaha mazhab Shafi'i, jika penjaga kanak-kanak atau penjaga orang gila membenarkan orang yang berada di bawah jagaannya menunggang binatang atau kenderaan, maka penjaga semestinya menanggung sebarang kemudaratan yang terjadi kepada kanak-kanak atau orang gila itu (Al-Nawawi, Muhy al-Din Abi Zakariyya Yahya Bin Sharaf, w.676H/1277M). Begitu juga jika seorang kanak-kanak menunggang kenderaan seperti motorsikal dan tiba-tiba berlaku perlanggaran dengan seseorang yang akhirnya mengakibatkan dia meninggal dunia, maka pembayaran diyat ditanggung oleh pihak 'aqilahnya.

Dalam kes lain, iaitu kes perlanggaran yang melibatkan dua orang wanita yang sedang hamil dan kedua-duanya meninggal dunia, serta mengalami keguguran, maka 'aqilah bagi kedua-dua pihak bertanggungan membayar separuh diyat berserta dengan empat kaffarah untuk diri kedua-dua wanita hamil dan janin-janin mereka dengan alasan bahawa kedua-dua wanita itu telah terlibat dalam kejadian yang melibatkan kematian empat nyawa. Selain itu, 'aqilah bagi setiap pihak juga bertanggungan membayar separuh ghurrah bagi setiap pihak yang terlibat seperti yang dikehendaki dalam kes keguguran iaitu, separuh ghurrah untuk janin pada satu pihak dan separuh ghurrah lagi untuk janin pihak yang satu lagi. Ini berbeza daripada tanggungan pembayaran diyat iaitu 'aqilah hanya bertanggungan terhadap pihak yang satu yang lagi sahaja, tidak untuk pada pihaknya (Al-Nawawi, Muhy al-Din Abi Zakariyya Yahya Bin Sharaf, w.676H/1277M).

Walaupun awalnya para sarjana Islam tidak sinonim dengan sistem pengangkutan di masa kini seperti kenderaan, keretapi, kapal terbang, kapal selam, roket dan lain-lain, namun pada hakikatnya mereka telah membincangkan aspek perlanggaran ini di dalam pengangkutan yang ada pada zaman mereka seperti haiwan tunggangan sebagai pengangkutan utama, kapal-kapal pelayaran dan gerabak. Berdasarkan penyelidikan kepustakaan, jelas menunjukkan bahawa teori dan undang-undang yang disimpulkan adalah daripada kefahaman umum mereka berdasarkan Al-Quran dan Sunnah yang boleh diterimapakai prinsip dan undang-undang tersebut sepanjang 
masa dan zaman tidak mengira sejauh mana perkembangan teknologi dalam mencipta pelbagai jenis pengangkutan.

\section{HAK DAN TANGGUNGJAWAB PENGGUNA JALAN RAYA}

Kegunaan jalan awam adalah satu hak awam bagi semua masyarakat dengan syarat yang tegas bahawa mereka tidak dibenarkan untuk memudaratkan mana-mana orang atau harta benda mereka ke dalam bahaya dan kemudaratan. Pengguna yang menggunakan jalan awam ini hanya bertanggungjawab jika dirinya melakukan kesalahan. Pendirian undang-undang dalam perkara ini telah dijelaskan di dalam Bada 'i Al-Sana ' $i$ bahawa:

"Perkara asas undang-undang ialah bahawa kegunaan jalan awam sama ada digunakan dengan berjalan kaki, menunggang haiwan, memandu atau ketika membimbing pemanduan adalah dibenarkan dengan syarat memelihara keselamatan pengguna yang lain dan sebarang perbuatan yang melanggar peraturan keselamatan adalah dilarang serta sebarang kemudaratan (kerosakan atau kecederaan) akibat perlanggaran tersebut hendaklah dipampas melainkan perbuatan itu tidak dapat dielakkan (Al-Kasani, 'Ala al-Din Abi Bakr Bin Mas'ud, w.587H/1191M)”.

Seterusnya Al-Sarakhsi turut menyebut prinsip yang sama di dalam pernyataan seperti berikut:

"Dan untuk memelihara keselamatan pengguna yang lain adalah hanya di dalam kes-kes yang boleh dikawal daripada berlaku perlanggaran dan bukan di dalam kes-kes yang tidak boleh dikawal oleh seseorang berdasarkan keupayaan semulajadi. Sekiranya pampasan itu perlu diberikan untuk kes-kes yang tidak boleh dikawal, maka pelaku itu tidak dibolehkan untuk menggunakan haknya untuk menggunakan jalan awam dikhuatiri akan menyebabkan kematian akibat perbuatan yang tidak boleh dikawal olehnya (AlSarakhsi, Shams al-Din, 1406H/1986M). 
Beliau seterusnya memberikan beberapa contoh suatu insiden yang tidak boleh dielakkan seperti haiwan yang menghentakkan kakinya pada batu-batu kecil menyebabkan batu tersebut terpelanting seterusnya menyebabkan kecederaan mata kepada pengguna jalan yang melalui di situ, maka penunggang itu tidak akan bertanggungan. Sama juga jika haiwan tunggangan itu terkencing atau membuang najis semasa berjalan atau dengan secara tiba-tiba berhenti untuk membuang najis atau jika terdapat air liur yang terkeluar daripada mulut haiwan itu dan jatuh ke atas jalan, maka penunggang itu tidak bertanggungan untuk apa-apa kemudaratan akibat tergelincir yang menyebabkan perlanggaran (Al-Sarakhsi, Shams al-Din, 1406H/1986M).

Seterusnya, berhubung perkara ini telah dinyatakan menurut pendapat Mazhab Shafi'e iaitu:

(a) Sekiranya pejalan kaki itu telah mendedahkan dirinya ke dalam bahaya kenderaan dan pemandu itu berupaya untuk mengelakkan perlanggaran akan tetapi tidak dapat melakukannya, maka beliau akan bertanggungan untuk membayar separuh diyat oleh kerana kematian itu juga telah disebabkan oleh kedua-dua mereka.

(b) Akan tetapi jika kemalangan itu di luar kawalan pemandu untuk mengelak dan tiada kecuaian di pihaknya seperti terdapat kerosakan pada brek secara tiba-tiba, maka pemandu tidak akan bertanggungan.

Al-Mas'udi telah menyebut dan merekodkan bahawa Imam Shafi'e menyatakan seperti berikut:

"Sekiranya seorang lelaki yang berdiri di atas jalan raya dan seorang yang bergerak telah melanggarnya menyebabkan kedua-duanya meninggal, maka tiada diyat untuk diberikan kepada orang yang bergerak dan diyat untuk orang yang berdiri itu hendaklah ditanggung oleh 'aqilah' orang yang bergerak. Begitu juga jika orang yang tidur di atas jalan raya dan dilanggar oleh orang yang sedang bergerak, maka tiada diyat ke atas diyat orang yang tidur di atas jalan 
raya (kerana dia cuai) dan diyat untuk orang yang bergerak itu hendaklah ditanggung oleh 'aqilah' orang yang tidur (Al-Nawawi, Muhy al-Din Abi Zakariyya Yahya bin Sharaf al-Nawawi. (w.676H/1277M)."

Seterusnya Imam Malik telah menyatakan di dalam kitab AlMudawwanah Al-Kubra:

"Jika haiwan itu dikawal oleh seseorang dan haiwan itu tiba-tiba menendang seorang lelaki sehingga mencederakan lelaki tersebut, maka apa yang harus diputuskan? Imam Malik menyatakan bahawa pemilik haiwan itu tidak akan bertanggungan melainkan haiwan yang menendang itu disebabkan oleh sesuatu yang telah dibuat terhadapnya dan menyebabkannya menendang (Sahnun ibn Sa'id ibn Habib at-Tanukhi, (t.t)"

Kenyataan lain yang dibuat oleh Imam Malik iaitu:

"Jika sebuah kapal berlanggar dengan sebuah kapal yang lain lalu kedua-dua buah kapal itu karam bersama-sama penumpang berserta harta benda di dalamnya, maka apakah keputusan itu? Imam Malik berkata: Jika perlanggaran itu disebabkan kekuatan angin yang menyebabkan perlanggaran yang tidak dapat dielakkan, maka tiada tanggungan ke atas keduadua kapal itu. Akan tetapi jika ia di dalam keupayaan untuk mengawalnya bagi mengelakkan perlanggaran dan mereka telah berbuat demikian, maka mereka adalah bertanggungan."

Pendirian Mazhab Hanbali berhubung hal perlanggaran ini telah dijelaskan seperti berikut:

"Penunggang, pemandu dan juru pandu kepada haiwan tunggangannya yang berada di bawah kawalannya adalah bertanggungan dan sebarang kemudaratan yang disebabkan oleh kaki atau mulut 
haiwan tersebut kecuali tendangannya itu bukan disebabkan oleh sesiapa (Al-Shaybani, Abu 'Abd Allah Muhammad Bin Hasan, 1986)."

Peri penting yang dapat disimpulkan di sini ialah:

(a) Keempat-empat mazhab telah bersepakat supaya memelihara kepentingan dan keselamatan masyarakat serta hak menggunakan jalan raya. Dalam erti kata lain, mereka memperluaskan skop hak kegunaan jalan awam akan tetapi turut mengenakan satu kewajipan yang ketat supaya menjauhi perbuatan yang boleh mendatangkan risiko yang tidak munasabah dan membahayakan orang lain. Setiap pengguna jalan bertanggungjawab untuk mengambil langkah berjagajaga secara munasabah agar perbuatan atau tinggalan itu dapat dielakkan sebagaimana pemandu secara munasabah boleh menjangkakan bahawa perbuatan itu boleh menyebabkan kemudaratan (Al-Basri, Al-Hassan Ali Bin Muhammad alMawardi, 1999).

(b) Pengguna jalan raya hanya bertanggungan ke atas kemudaratan yang disebabkan oleh kecuaiannya dan perlanggaran kewajipan berhati-hati.

(c) Pengguna tidak bertanggungan bagi kemudaratan yang disebabkan situasi di luar keupayaan seorang yang munasabah untuk mengelakkannya.

(d) Pembelaan bagi perbuatan yang tidak dapat dijangkakan seperti datangnya angin ribut.

Ulama Hanafi pula berpendapat bahawa penunggang haiwan adalah bertanggungan bagi kemudaratan yang disebabkan sesuatu yang keluar dari mulut atau kaki hadapan haiwan itu kerana ia termasuk di dalam kapasiti kawalan tali kekang kuda atau cara-cara lain yang boleh untuk mengawal haiwan tersebut. Begitu juga ia boleh menjangkakan satu situasi yang akan terjadi melalui sifat haiwan itu. Pengecualian kepada tanggungan bagi kemudaratan yang disebabkan oleh kaki belakang dan ekor haiwan kerana penunggang tidak dapat melihat secara keseluruhan di belakang haiwan itu. Oleh itu, tiada hukuman kaffarah ke atas penunggang di dalam situasi tersebut jika kemudaratan itu menyebabkan kematian mangsa (AlBasri, Al-Hassan Ali Bin Muhammad al-Mawardi, 1999). 
Oleh yang demikian, dapat dilihat bahawa terdapat perbandingan undang-undang daripada Mazhab Hanafi dengan situasi kini yang secara amnya telah diterima di dalam prinsip peraturan bahawa apabila sebuah kenderaan yang dilanggar dari belakang, ia menjadi satu prinsip tanggungan tegas bahawa pemandu itu bertanggungan bagi semua kemudaratan akibat perbuatan cuainya kerana ia bukan di dalam kapasiti kawalan pemandu kenderaan di hadapan untuk mengambil kewajipan berjaga-jaga terhadap apa-apa yang datang dari arah belakangnya.

Di dalam Al-Majmu' telah dijelaskan seperti berikut:

"Sekiranya pemandu telah mematuhi semua peraturan lalu lintas tetapi secara mengejut memberhentikan kenderaannya bagi mengelakkan bahaya yang datang, kemudiannya ada kenderaan lain yang merempuh dari belakang hingga menyebabkan pemandu tersebut meninggal, maka:

(i) Jika pemandu kenderaan di hadapan yang seharusnya memberikan isyarat sebelum berhenti tetapi tidak berbuat demikian, maka pemandu itu adalah bertanggungan bagi diyat ringan (diyat mukhaffafah).

(ii) Akan tetapi, jika pemandu itu memberikan isyarat yang wajar dilakukan, maka pemandu adalah tidak bertanggungan dengan kematian kerana mangsa akibat kecuaiannya sendiri melanggar pemandu kenderaan di hadapan.

Begitu juga apabila satu kemudaratan itu diakibatkan oleh haiwan yang diterangkan di dalam Al-Mudawwanahtul Kubra di mana seorang lelaki yang menanyakan kepada Imam Malik jika lelaki itu memberhentikan haiwannya di atas laluan awam yang mana ia tidak dibenarkan untuk berbuat demikian lalu haiwan itu mengakibatkan kemudaratan, maka dia adalah bertanggungan bagi akibat tersebut (Sahnun ibn Sa'id ibn Habib at-Tanukhi, (t.t)). Keskes yang dikenalpasti telah dijelaskan di dalam sumber-sumber dari Imam Hanbali dan Imam Hanafi (Al-Shaibani, Abu 'Abd Allah Muhammad Bin Hasan,1983; Al-Sarakhsi, Abi Bakar Mohammad Ibn Ahmad Al Sarkhasi, w.483H./1090 M.). Berikutnya di dalam kitab Al-Muhadhdhab yang mana Imam Shafi'e memberikan beberapa contoh lain berhubung konsep liabiliti. Contohnya jika 
haiwan tersebut terkencing di atas laluan awam dan mengakibatkan seseorang tergelincir lalu jatuh meninggal dunia, maka pemilik haiwan itu bertanggungan (Al-Shirazi, Abu Ishak, 1412H/1992M).

Sekiranya air kencing, najis dan air liur haiwan yang menyebabkan kemudaratan atau kematian, maka pemilik haiwan itu bertanggungan. Contoh tersebut boleh diqiyaskan kepada situasi masa kini iaitu tanggungan adalah ke atas pemandu yang memberhentikan kenderaannya untuk menukar minyak kenderaan atau meninggalkan tayar kenderaan yang rosak di atas jalan raya sehingga menyebabkan orang lain menanggung kemudaratan akibat perbuatan cuai itu.

Di dalam beberapa rujukan, prinsip di dalam beberapa kes berikut turut diterangkan:

"Jika mana-mana bahagian atau mana-mana muatan yang dibawa oleh haiwan itu terjatuh lalu menimpa seseorang hingga terbunuh, maka pemilik haiwan itu hendaklah bertanggungan kerana ia sepatutnya boleh dielakkan iaitu dengan mengikat muatan dengan lebih berhati-hati (Al-Sarakhsi, Abi Bakar Mohammad Ibn Ahmad Al Sarkhasi, w.483H./1090 M)."

Manakala di dalam kes yang melibatkan perbuatan yang tidak dapat dijangkakan atau dielakkan yang mengecualikan tanggungan seperti misalan yang dinyatakan oleh Mazhab Maliki iaitu sekiranya berlaku perlanggaran antara dua buah kapal yang disebabkan angin yang bertiup kencang ketika pelayaran, maka kapten dan krew kapal tersebut tidak bertanggungan. Pendapat ini telah diterima oleh semua mazhab (Sabiq, al-Sayyid, 1414H/1994M).

\section{PRINSIP PENYEBAB DALAM KEMALANGAN JALAN RAYA (AL-MUBASHIR WAL MUTASABBIB)}

Para sarjana Islam telah menerangkan satu prinsip iaitu 'penyebab' berhubung kemalangan di jalan raya. Prinsip ini telah dibincangkan di dalam tajuk "Al-Mubashir Wal Mutasabbib". Al-Mubashir merupakan pelaku langsung perbuatan itu dan al-Mutasabbib adalah orang yang menyebabkan akibat dan perbuatan yang menyebabkan pelaku langsung melakukan perbuatan tersebut. Contohnya seperti 
seseorang yang mencucuk haiwan itu lalu menyebabkan haiwan itu melompat, menendang lalu mengakibatkan kemudaratan. Secara amnya, kemudaratan itu hendaklah disebabkan oleh defendan. Perbincangan mengenai prinsip penyebab ini amat terperinci dan kadang-kala terlalu rumit untuk dirungkai kerana tajuk ini boleh dianggap kompleks di kalangan sarjana masa kini. Akan tetapi, ia boleh dikatakan bahawa di dalam menentukan dan menetapkan hubungan antara perbuatan dan kemudaratan, maka para sarjana ini telah mengikut prinsip penyebab dan kesannya secara saintifik dan kefahaman tentang kesan fizikal.

Dengan mengambil contoh berikut di dalam Al-Mabsut:

"Jika seseorang yang menunggang haiwan di atas laluan awam dan datang seorang lelaki lalu mencucuk dan memukul haiwan itu lalu haiwan itu menendang dan menyebabkan kematian pengguna jalan yang lain, maka lelaki tersebut (pelaku) adalah bertanggungan berbanding penunggang haiwan itu. Oleh kerana perbuatan mencucukdan memukul haiwan sesuatuyang tidak dikehendaki dan oleh itu, pelaku bertanggungan kerana menyebabkan kemudaratan. Ia telah dijadikan sebagai satu ketetapan dan keputusan yang dibuat oleh Saidina Umar Al-Khattab dan Mas'ud ra (Al-Sarakhsi, Abi Bakar Mohammad Ibn Ahmad Al Sarkhasi, w.483H./1090 M).

Kemudiannya beliau menyambung:

"Jika haiwan itu menendang pelaku yang dia sendiri mencucuk haiwan itu dan menyebabkan pelaku itu terbunuh, maka tiada sesiapa yang akan bertanggungan. Jika pelaku perbuatan itu mencucuk menyebabkan penunggang terjatuh lalu meninggal, maka bayaran diyah penunggang hendaklah ditanggung oleh 'aqilah pelaku yang mencucuk. Prinsip yang sama turut terpakai jika haiwan itu sedang berdiri atau berjalan. Akan tetapi jika pelaku itu diberi izin oleh penunggang untuk melakukan sedemikian, maka kedua-duanya adalah bertanggungan." 
Harus diingatkan bahawa 'mutasabbib' iaitu pelaku/penyebab hendaklah bertanggunan hanya sekiranya dia adalah bersalah di dalam perbuatannya. Jika tidak bersalah sebagai contoh apabila haiwan itu memijak kakinya (al-mutasabbib) dan dia mencucuk haiwan itu untuk mengeluarkan kakinya daripada pijakan haiwan itu, maka ia bukan di bawah tanggungannya.

\title{
'AQILAH SEBAGAI PENANGGUNG INSURANS DALAM KES KEMALANGAN JALAN RAYA
}

Prinsip am di dalam perundangan Islam bahawa tiada sesiapa yang akan bertanggungjawab bagi kesalahan yang dilakukan oleh orang lain. Berdasarkan firman Allah di dalam Al-Quran:

\begin{abstract}
"Dan tiadalah (kejahatan) yang diusahakan oleh tiap-tiap seorang melainkan orang itulah sahaja yang menanggung dosanya; dan seseoraang yang boleh memikul tidak akan memikul dosa perbuatan orang lain (bahkan dosa usahanya sahaja: kemudian kepada Tuhan kamulah tempat kamu kembali, lalu ia menerangkan kepada kamu akan apa yang kamu berselisih padanya (Surah Al-An'aam 6:164).'
\end{abstract}

Baginda Nabi Muhammad SAW mengiayakan prinsip tersebut menerusi ayat Al-Quran apabila baginda menjelaskan kepada seorang ayah yang menemani anak lelakinya dan berkata:
"Seseorang tidak dihukum lantaran kejahatan bapanya tidak pula lantaran kejahatan saudaranya (An-Nasai', Abu Abdur Rahman Ahmad ibn Shuayb ibn Ali ibn Sinan ibn Bahr Al-Khurasani An-Nasai, w.303H)”.

Walau bagaimanapun, di dalam kes lain melibatkan pembunuhan seumpama sengaja di mana dua orang wanita dari kabilah Huzail telah bergaduh lalu salah seorang di antara keduanya membaling lawannya dengan seketul batu menyebabkan terbunuh dan juga janin yang dikandungnya di dalam perutnya, lalu Rasulullah SAW memutuskan bahawa diyat wanita yang terbunuh itu ditanggung pembayarannya oleh 'aqilah keluarga yang membunuh (Al- 
Bukhari, Abu 'Abd Allah Muhammad Bin Ismail Bin Ibrahim Bin Al-Mughirah al-Bukhari al-Ju’fi. (1396H/1976M).

Dan mereka berpendapat bahawa kawalan terhadap diri pelaku merupakan tanggungjawab bersama keluarganya sekiranya mereka tidak mengawalnya dengan betul dan sempurna, bermakna mereka telah cuai dengan tanggungjawab mereka. Maka dengan kecuaian inilah mereka diwajibkan menanggung sebahagian dari natijah perbuatan yang dilakukannya. Baginda Rasulullah SAW menghendaki agar konsep 'aqilah ini menjadi pengecualian kepada prinsip am, bekerjasama dan sifat bermurah hati sepertimana yang diperintahkan oleh Allah SWT betapa pentingnya objektif bekerjasama secara kolektif di dalam semua perkara kebaikan seperti yang diamalkan di dalam takaful masa kini yang berperanan penting di dalam masyarakat termasuk menjaga psikologi dan kebajikan ekonomi.

\section{KONSEP ' $A Q I L A H$ DALAM KES KEMLANGAN JALAN RAYA MENURUT PERSPEKTIF ISLAM}

Para sarjana Islam mempunyai pelbagai pandangan berhubung mereka yang terdiri daripada 'aqilah. Dalam konteks diyat, perkataan 'aqilah diambil dari kata akar 'aqal yang bermakna orang yang membayar diyat (Al-Jurjani, Abu Al-Hasan Ali Bin Muhammad Bin Ali, 2000). Pengertian 'aqilah dalam ilmu fiqh Islam adalah sekumpulan orang yang menanggung pembayaran diyat (Awdah, 'Abdul Qadir, 1407/1987). 'Aqilah terdiri daripada saudara-saudara lelaki seorang dari sebelah ayah yang sudah berusia baligh, kaya dan berakal termasuklah orang buta, penderita penyakit kekal dan orang tua tetapi dengan syarat mereka adalah kaya. Tidak termasuk dalam kategori 'aqilah adalah saudara perempuan, saudara miskin, anak kecil, orang gila dan tidak berlainan agama dengan pelaku jenayah memandangkan prinsip 'aqilah adalah untuk saling tolongmenolong sedangkan mereka yang berlainan agama tidak berhak untuk saling menolong dalam masalah ini.

Menurut Al-Kasani (Al-Kasani, 'Ala al-Din Abi Bakr Bin Mas'ud, w.587H/1191M). berhubung jumlah yang akan diambil daripada setiap 'aqilah tidak lebih daripada 3 atau 4 dirham yang akan 
diambil dari setiap ahli dan tidak lebih dari itu. Jika ahli-ahli 'aqilah itu dalam jumlah yang kecil, maka kabilah yang paling dekat akan dimasukkan sebagai 'aqilah agar beban tanggungan pembayaran itu dapat dikurangkan. Demikianlah Rasulullah SAW berpegang kepada objektif kefahaman tentang 'aqilah dengan satu justifikasi iaitu saling bekerjasama dan tolong-menolong di dalam kesusahan selaras dengan objektif takaful sosial untuk membantu mangsa-mangsa yang tidak bernasib baik akibat kemalangan jalan raya menerusi pengagihan tanggungan dalam pembayaran pampasan ganti rugi di kalangan ahli dan saudara-mara seIslam yang mempunyai hubungan dengan pelaku (defendan).

Sementara itu, pendapat para fuqaha mazhab Hanafi bersetuju agar sistem 'aqilah ini dirujuk sebagai suatu institusi atau organisasi yang berkenaan di mana pihak pesalah boleh mendapatkan bantuan dan sokongan dalam bentuk kewangan termasuklah skim insurans kenderaan, institusi pengajian, institusi perbankan, kementerian atau jabatan ketenteraan (Al-Baghdadi, Abu Muhammad Bin Ghanim Bin Muhammad, 1308H/1890H). Oleh yang demikian, objektif dalam takaful diterima pakai dan ia amat dialu-alukan agar dapat mewujudkan satu sistem yang menghendaki setiap industri atau yang berkaitan dengan aktiviti khusus supaya membayar satu jumlah khas secara sukarela atau jumlah yang diwajibkan untuk bulanan atau tahunan secara kolektif dapat memikul beban pembayaran pampasan ganti rugi.

Kemudaratan yang dilakukan secara tidak sengaja atau seumpama sengaja yang dilakukan oleh salah seorang pelaku dengan syarat insurans/takaful hendaklah bukan bertujuan manjalankan aktiviti komersil yang boleh tercemar dengan unsur-unsur perjudian, riba dan juga gharar (satu terma teknikal yang digunakan oleh para sarjana Islam untuk menunjukkan terdapat risiko yang tidak munasabah atau ketidakpastian di dalam kontrak).

\section{APLIKASI KEPADA MASYARAKAT KINI}

Peraturan dan undang-undang lalu lintas adalah bertujuan mengawalselia trafik serta membantu masyarakat supaya suatu kemudaratan dan bahaya di atas jalan raya itu boleh dielakkan. 
Oleh yang demikian, setiap semua masyarakat di dalam sesebuah negara adalah terikat untuk mematuhinya sepertimana yang dituntut di dalam agama dan tanggungjawab di sisi undang-undang sebagaimana yang dijelaskan di dalam tajuk 'adab al-tariq' iaitu yang dimaksudkan ialah undang-undang lalu lintas. Dalam konteks masa kini yang melibatkan semua kenderaan yang terdapat di jalan raya sama ada dipandu oleh pemilik atau penyewa kenderaan adalah bertanggungjawab sepenuhnya terhadap kenderaan yang mereka pandu atau tunggang di jalan raya. Contoh-contoh kemalangan yang boleh dikawal telah dijelaskan melalui analogi dengan situasi kawalan pada haiwan. Pemandu yang sengaja memandu secara merbahaya, lalai, membuata tuli, memandu dalam keadaan mabuk, melebihi had laju boleh dianggap cuai kerana semua perkara tersebut boleh dikawal.

Amalan oleh mahkamah di Malaysia, kesalahan-kesalahan seperti memandu dengan melulu atau membahayakan sehingga menyebabkan kematian, memandu dengan tidak cermat dan tidak bertimbang rasa, memandu semasa berada di bawah pengaruh minuman yang memabukkan atau dadah telah diperuntukkan di dalam Akta Pengangkutan Jalan 1987 jika disabitkan boleh dihukum penjara atau denda. Pesalah akan didakwa di bawah pertuduhan jenayah di bawah prosedur jenayah dan Akta Pengangkutan Jalan 1987. Sementara itu, dalam prosiding yang lain tuntutan pampasan ganti rugi kes kemalangan jalan raya boleh dituntut di bawah prosedur tuntutan sivil berdasarkan Akta Undang-Undang Sivil 1956. Dalam skop tuntutan pampasan ganti rugi, undang-undang sivil telah memperuntukkan pampasan ganti rugi khas dan ganti rugi am kepada pihak mangsa atau waris si mati sebagai award. Award pampasan di dalam penghakiman ini pula akan diselesaikan oleh pihak insurans mengikut terma-terma yang telah ditetapkan oleh mahkamah.

Ia berbeza dengan amalan di bawah perundangan Islam di mana sekiranya kecuaian tersebut boleh dinilai menurut syarak, maka wujud tanggungan dan liabiliti yang perlu dipikul oleh pelaku cuai itu. Ini jelas bahawa kecuaian merupakan akibat daripada perbuatan seseorang yang tidak berhati-hati dan tidak berniat untuk mewujudkan akibat tersebut tetapi akhirnya terjadi hasil daripada kelalaian atau kecuaiannya. Liabiliti boleh dilihat apabila pelaku 
yang cuai diwajibkan menggantikan kerosakan dalam bentuk harta sepadan atau senilai atau dikehendaki membayar sesuatu sebagai gantian seperti diyat, arsy (bayaran sejumlah wang atau harta atau sebahagian daripada kadar diyat yang dikenakan sebagai pampasan) atau seumpama dengannya.

Sehubungan itu, sesuatu kecuaian akan disabitkan dengan sesuatu hukum apabila kejadian yang berlaku menunjukkan berlaku kecuaian tanpa mengira sama ada pihak yang terlibat benar-benar cuai atau tidak. Perundangan Islam tidak mensyaratkan adanya penyiasatan bagi membuktikan kecuaian untuk membolehkan pelaku itu dikenakan untuk membayar pampasan ganti rugi. Sebaliknya, hanya dengan satu syarat sahaja bagi tujuan itu iaitu wujudnya kejadian yakni perlanggaran yang menunjukkan berlakunya kecuaian. Oleh itu, pelaku cuai akan dikenakan untuk membayar ganti rugi bagi menampung kemudaratan atau kerugian serta memastikan setiap mangsa atau keluarga mangsa memperoleh hak masing-masing (Mustofa Al-Khin, Mustofa Al-Bugho, Ali Asy-Syarbaji, 1998).

Rasional menurut syariat Islam bahawa sikap dan etika yang digunapakai oleh kebanyakan undang-undang sekular kini terhadap tiada liabiliti dalam kemalangan yang tidak dapat dielakkan serta tiada liabiliti bagi kejadian-kejadian kuasa Tuhan (acts of God), sebagaimana kebanyakan masyarakat telah tersalah faham tentang ayat di dalam surah Al-Nisa dan Al-Maidah bahawa adalah tidak wajar dan tidak adil kerana ia boleh membantutkan kemajuan negara dan pertumbuhan ekonomi oleh kerana kebanyakan orang akan berputus asa di dalam aktiviti projek dan perdagangan jika mereka terpaksa berhadapan dengan dilema untuk memikul beban kos akibat kemudaratan dan kecederaan sama ada kecuaian itu satu akibat yang boleh dijangkakan atau tidak. Adalah satu keperluan sosial dan ekonomi bahawa masyarakat hendaklah bertanggungjawab hanya apabila mereka melakukan kecuaian dan mengakibatkan kemudaratan.

Tambahan pulajika peserta takaful dan insurans mematuhi secaraketat segala undang-undang lalu lintas namun, kemalangan masih berlaku, maka elemen-elemen kecuaian dan kebolehjangkaan mengakibatkan perlanggaran dan pertembungan, akan dipertimbangkan sepenuhnya untuk memutuskan tahap kebertanggungan liabiliti di dalam sivil dan 
kecuaian jenayah. Ini merupakan satu kerumitan dan mengundang kepada proses yang panjang di mana pelaku akan dibicarakan di bawah prosiding jenayah jika disabitkan dan kemudiannya dibicarakan di dalam prosiding sivil bagi tuntutan sivil ganti rugi akibat kemalangan tersebut. Oleh itu, di dalam ketiadaan apa-apa bentuk kesalahan atau kecuaian, operator takaful yang berfungsi sebagai 'aqilah hendaklah tidak bertanggungan. Oleh itu, jika peserta telah mengambil semua langkah berhati-hati yang perlu dan secara tegas mematuhi undang-undang lalu lintas, namun jika sesebuah kenderaan lain memasuki laluan sah dan menyebabkan kematian, maka dalam hal ini tiada tanggungan ke atas pemandu itu jika jelas di sini bahawa tindakan si mati itu yang menyebabkan kematiannya yang tidak boleh dielakkan.

Sekiranya pemandu yang melanggar peraturan lalu lintas dan menyebabkan kemalangan, maka pemandu itu dengan sendirinya akan bertanggungan bagi semua tuntutan pampasan serta boleh dihukum ta'zir. Harus diingatkan bahawa perbezaan antara seekor haiwan dengan sebuah kenderaan automobil adalah haiwan merupakan makhluk yang bernyawa dan mempunyai nafsu dan kecenderungan untuk bertindak di luar kawalan penunggang yang mengawalnya sementara itu, kes perlanggaran yang melibatkan kenderaan automobil sememangnya mempunyai sistem kawalan lengkap dan ia tidak boleh bergerak dengan sendirinya tanpa kawalan pemandu. Kenderaan adalah satu suatu struktur yang boleh bergerak atau digerakkan atau digunakan bagi membawa manamana orang atau benda dan yang bersentuhan dengan bumi apabila bergerak (Akta Pengangkutan Jalan 1987, seksyen 2).

Melalui pencapaian dalam kemodenan dan kecanggihan teknologi, sistem pengangkutan dapat mempertingkatkan lagi kualiti kenderaan sebagai alat pengangkutan dan aspek pengawalan pada sistem kenderaan tersebut dapat diperlengkapkan. Para sarjana Islam menerusi teori dan konsep 'al-mubashir dan al-mutasabbib' sepertimana yang dijelaskan amat bersesuaian dengan situasi apabila pemandu itu memberhentikan kenderaannya ketika menunggu lampu isyarat bertukar hijau lalu kemudiannya sebuah kenderaan lain melanggar belakang kenderaannya sehingga menyebabkan kecederaan dan kerosakan pada harta benda maka, pemandu yang melanggar dari belakang adalah bertanggungan sepenuhnya untuk semua kehilangan dan kerugian yang dialami. 


\section{KESIMPULAN}

Teori 'penyebab' di dalam tajuk 'al-mubashir dan al-mutasabbib' ini akan kekal sahih untuk diputuskan di dalam situasi-situasi yang boleh dijangkakan sama ada perlanggaran yang akan berlaku di darat, lautan atau di udara. Oleh yang demikian, pandangan para sarjana Islam tentang tanggungan amat jelas walaupun di dalam situasi lain seperti kemalangan yang berlaku akibat kecuaian pihak yang berkaitan dalam membuat struktur jalan, jambatan, terowong dan lain-lain yang bersangkutan dengan jalan raya, maka pihak-pihak yang terlibat hendaklah bertanggungjawab dan bertanggungan, bukan pada pemandu tersebut sekiranya pemandu tidak bersalah dan tidak cuai. Sehubungan itu, undang-undang berhubung ganti rugi kehilangan nyawa dan kehilangan anggota badan menjadi tanggungjawab bersama di kalangan pakar perundangan dan pakar perubatan dalam membentuk dan merancang bagi mendefinisikan bentuk kecederaan dan kemudaratan agar pemberian pampasan yang komprehensif dan adil dapat diberikan. Selain itu, hukuman dan bentuk undang0undang ini juga perlu mengambil kira perbuatan pelaku sebagai langkah dalam pemberian pampasan mangsa yang terkorban.

\section{BILBIOGRAFI}

Al-Quran, Tafsir pimpinan ar-Rahman kepada pengertian al-Quran. (2010). Cet. 14. Dar al-Kitab Malaysia (Jabatan Perdana Menteri).

Abdul Basir Mohamad. (2009). Undang-undang tort Islam. Dewan Bahasa Dan Pustaka. Kuala Lumpur, 368.

Abu Abdullah Muhammad ibn Ismail al-Bukhari. (1983). Sahih alBukhari bi Hashiyah al-Sindi, kitab al-isti'dhan, Matba'ah Dar Ihya' al-Kutub al- 'Arabiyyah, 86.

Ahmad Fathi al-Dirini. (1998). Nazariyyah al-Ta'assuf fi Isti'mal al-Haqq fi al-Fiqh al-Islami, Beirut: Mu'assasah al-Risalah, 12-22.

Akta Pengangkutan Jalan 1987 (Akta 333).

'Ala al-Din al-Samarqandi. (1993). Tuhfah al-Fuqaha', j.3, Beirut: Dar al-Kutub al- 'Ilmiyyah, 123. 
Al-Baghdadi, Abu Muhammad bin Ghanim bin Muhammad. (1308H/1890M). Majma' al-Damanat. Kaherah: al-Matba'ah al-Khayriyyah bi al-Jamaliyyah, 189.

Al-Basri, Al-Hassan Ali bin Muhammad al-Mawardi. (1999).

Mukhtasar Muzni. Beirut, Lubnan: Dar al-Kutub alAlamiyyah, 180,189.

Al-Bukhari, Abu 'Abd Allah Muhammad bin Ismail bin Ibrahim bin Al-Mughirah al-Bukhari al-Ju'fi. (1396H/1976M). Al-Jami' al-Sahih (Sahih al-Bukhari). Kaherah, 1314-1315H. Bahasa Arab dengan terjemahan bahasa Inggeris oleh Muhammad Muhsin Khan. 9 Juzuk. Turki: Hilal Yayinlari, 223.

Al-Hattab, Abu 'Abd Allah Muhammad bin 'Abd al-Rahman alMaghribi. (1412H/1992M). Mawahib Al-Jalil Li Sharh Mukhtasar Khalil. Cairo: Darul Fikr.

Al-Jurjani, Abu Al-Hasan Ali bin Muhammad bin Ali. (2000). AlTa'rifat. Beirut: Dar Al-Kutub Al- 'Ilmiyah, 109.

Al-Kasani, 'Ala al-Din Abi Bakr bin Mas'ud. (w.587H/1191M). Bada'i Al-Sanai fi Tartib al-Shara'i. Beirut: Darul Kutubil Elmiyyah, 272.

Al-Khiraqi, Umar bin al-Husayn. (1402H/1982M). Mukhtasar al-Khiraqi fi al-Madhhab al-Hanbali. Beirut: Matba'ah Munayminat al-Hadithah, 117.

Al-Khirshi, Abu 'Abd Allah Muhammad bin 'Abd Allah. (1317H/1899M). Sharh al-Khirshi 'ala Mukhtasar Khalil. Juzuk 8. Kaherah: al-Matba'ah al-Kubra al-Amiriyyah, 12.

Al-Marghinani, Burhan al-Din Abi al-Hasan 'Ali bin Abi Bakr bin 'Abd al-Jalil al-Rushdani. (593H/1196M). Al-Hidayah Sharh Bidayat al-Mubtadi. Juzuk 4. Al-Maktabah al-Islamiyyah, 197-198, 199.

Al-Nawawi, Muhy al-Din Abi Zakariyya Yahya bin Sharaf alNawawi. (w.676H/1277M). Minhaj al-Talibin wa 'Umdat alMuftin. Maktabah al-Thaqafah, 285.

Al-Nawawi, Muhy al-Din Abi Zakariyya Yahya bin Sharaf alNawawi. (w.676H/1277M). Al-Majmu Sarhul Muhadhdhab. Beirut: Darul Fikr, 28-29.

Al-Sarakhsi, Abi Bakar Mohammad ibn Ahmad Al Sarkhasi. (w.483H./1090 M). Al-Mabsut. Beirut: Darul Marifah, 2, 188$189,190,445$.

Al-Shaybani, Abu 'Abd Allah Muhammad bin Hasan. (1983). Nail al-Maarib. Jilid 1. Kuwait: Maktabatul Falah, 448, 450. 
Al-Shirazi, Abu Ishak. (1412H/1992M). Al-Muhadhdhab fi Fiqh alImam al-Shafi'i. Cairo: Isaul Babil Halabi Press. Jil. 2, 194. Al-Zayla 'i, Fakhral-DinUthman binAli al-Hanafi.(w.762H/1360M). Tabyin al-Haqa 'iq, Juzuk 5. Kaherah: Dar al-Kitab al-Islami, 151.

An-Nasai', Abu Abdur Rahman Ahmad ibn Shuayb ibn Ali ibn Sinan ibn Bahr Al-Khurasani An-Nasai. (w.303H). Sunan AnNasa'i, j.2, 251.

Asy-Syahid Sayyid Qutb Rahimahullah. (2000M/1420H) Tafsir Fi Zilalil Quran. Jilid 11. Terjemahan Yusoff Zaky Haji Yaakob. Penerbitan Warisan Sdn. Bhd, 75-77.

Awdah, 'Abdul Qadir. (1407/1987). Al-Tashri' al-Jina'I al-Islami. Terjemahan dalam bahasa Inggeris. S. Zakir Aijaz. Criminal Law of Islam. Jilid.3, 71.

Chelliah, Kandiah. (1996). "No fault liability for motor vehicle accident claims: Tan Sri Harun Hashim's proposal and other factors that need consideration", [1996] 4 CLJ c.

Ibn Duwayyan, Ibrahim bin Muhammad bin Salim. (1404H/1984M). Manar al-Sabil. Juzuk 2. Beirut: al-Maktabah al-Islami, 334. Ibn Farhun. (1995). Tabsirah al-Hukkam fi Usul al-Aqdiyah wa Manhaj al-Ahkam, j.1, Beirut: Dar al-Kutub al- 'Ilmiyyah, 251.

Ibn Hajar, al-'Asqalani, Shihab al-Din Abu al-Fadhl Ahmad bin Ali bin Muhammad. (1414H/1993M). Bulugh al-Maram min Adillat al-Ahkam. Terjemahan Bahasa Inggeris oleh Muhieddin al-Selek. Beirut: Dar al-Fikr.

Ibn Manzur, Muhammad Ibn al-Mukarram al-Khazraji. (12331312M/ 711H), Lisanul Arab, 20 j., Beirut: Dar al-Sadir, 96. Ibn Juzayy, Abu al-Qasim Muhammad bin Ahmad bin Juzayy alKalabi al-Gharnati. (1293-1340M). Al-Qawanin al-Fiqhiyyah. Beirut: Maktabah Usamah bin Zayd, 218.

Ibn Qudamah, Muwaffaq al-Din Abu Muhammad 'Abd Allah bin Ahmad bin Muhammad (w.620H/1223M). Al-Mughni wa alSharh al-Kabir. 10 Juzuk. Beirut: Dar al-Kutub al- 'Ilmiyyah, 487.

Ibn Rushd, Muhammad bin Ahmad bin Muhammad bin Ahmad bin Rushd al-Qurtubi al-Andalusi. (w.595H/1198M). Bidayat alMujtahid wa Nihayat al-Muqtasid. Juzuk 2. Beirut: Dar alFikr, 313. 
JP Singhal. (2003). Law of damages and compensation. New Delhi: LexisNexis Butterworths.

Lisanul Arab. (1955). Beirut: Darul Sadir Publications, Jil. 13.

Malik bin Anas. (1403H/1982M). Abu 'Abd Allah. Muwatta' Imam Malik. Terjemahan dalam bahasa Inggeris oleh Muhammad Rahimuddin, New Delhi: Kitab Bhavan, 1410H/1982M, dan terjemahan dalam bahasa Inggeris oleh Aishah Abdarahman at-Tarjumana dan Yaqub Johnson. Diwan Press.

Malik bin Anas. (1988) Al-Muwatta. Beirut: Al-Maktabahtut Taqafiah. j.1.

Malik bin Anas. (1994) Al-Mudawwanahtul Al-Kubra (Riwayat Imam Sahnun). Darul Kutub Al-Ilmiyah, Beirut-Lebanon, 666.

Mustofa Al-Khin, Mustofa Al-Bugho, Ali Asy-Syarbaji. (1998). Fiqh Al-Manhaj ala Mazhab Imam Syafie, j.3, Damsyik: Dar Al-Qalam, 403.

Sabiq, al-Sayyid. (1414H/1994M). Fiqh al-Sunnah. Kaherah: Dar al-Fath lil al-I'lam al- 'Arab, 463-464.

Sahnun ibn Sa'id ibn Habib at-Tanukhi (t.t). Al-Mudawwanah alKubra, j.11, Beirut: Dar al-Sadir, 506.

Sayyid Sabiq, Fiqih Sunnah, Dar Fath Lil i'lami Al-Arabiy, Penterjemah Abdurrahim dan Masrukhin. (2009). Fikih Sunnah Jil.4, Cakerawala Publishing, Jakarta, 464.

Shamsuddin b. Muflih. (1985). Kitabul Furu. Beirut: Alamul Kutub, Jil. 6.

Siti Zubaidah Ismail. (2012). The modern interpretation of Diyat formula for quantum of damages: The Case of homicide and personal injuries. Arab Law Quarterly, 26(3), 361-379.

Qadikhan, al-Hasan Ibn Mansur. (2009). Fatawa Qadikhan $f i$ Madhhab al-Imam Al-Azam Abi Hanifah al-Nu'man. Beirut: Dar al-Kutub al-Ilmiyyah, 444.

Qutb, Sayyid. (1400H/1980M). Fi Zilal al-Quran. Beirut/Kaherah: Dar al-Shuruq.

Wahbah al-Zuhayli. (1404H/1982M). Nazariyyat al-Dhaman. Dirasah Muqaranah. Damsyik: Dar al-Fikr, 14.

Kementerian Pengangkutan Malaysia. (2018, 18 April). Buku statistik keselamatan jalan raya. Capaian daripada http:// www.jkjr.gov.my

Samsuri, H. (2018, 22 November). Berita domestik. The Sun Daily. Capaian daripada https://careta.my 